\title{
The synthesis of silver, zinc oxide and titanium dioxide nanoparticles and their antimicrobial activity
}

\author{
Kate Kotlhao ${ }^{1}$, Moloko D.T. Madiseng ${ }^{2}$, Fanyana M. Mtunzi ${ }^{1}$, Vusumzi E. Pakade ${ }^{1}$, \\ Sekomeng J. Modise ${ }^{3}$, Neelan Laloo ${ }^{2}$, Michael J. Klink ${ }^{1,2^{\star}}$ \\ ${ }^{I}$ Department of Chemistry, Vaal University of Technology, Andries Potgieter Boulevard, Vanderbijlpark, 1900, South Africa \\ ${ }^{2}$ Department of Biotechnology, Vaal University of Technology, Andries Potgieter Boulevard, Vanderbijlpark, 1900, South \\ Africa ${ }^{3}$ Institute of Chemical and Biotechnology, Vaal University of Technology, Andries Potgieter Boulevard, \\ Vanderbijlpark, 1900, South Africa
}

*Corresponding author: Tel: (+27) (0)16950 7507; E-mail: michaelk1 @ vut.ac.za

Received: 07 July 2017, Revised: 10 July 2017 and Accepted: 26 July 2017

DOI: $10.5185 / \mathrm{amp} .2017 / 803$

www.vbripress.com/amp

\begin{abstract}
Three different types of nanoparticles were synthesised in this study, viz silver $(\mathrm{Ag})$, zinc oxide $(\mathrm{ZnO})$ and titanium dioxide $\left(\mathrm{TiO}_{2}\right)$ using different chemical methods. These materials were then characterised using Transmission Electron Microscopy (TEM), Fourier Transform Infra-Red Spectroscopy (FTIR), Ultraviolet Visible Spectroscopy (UV-Vis) and Thermal Gravimetric Analysis (TGA). The materials were also tested for anti-bacterial activity. TEM showed that the particles were in the nano-size range $(1-100 \mathrm{~nm})$. FTIR and UV-Vis Spectroscopy showed the different absorption bands of the synthesised nanoparticles, respectively. Silver nanoparticles showed greater antibacterial activity against several bacteria than titanium dioxide and zinc oxide nanoparticles. The highest inhibition was observed for Klebsiella pneumoniae. The results showed that antimicrobial activity of nanoparticles increases with increasing concentration of the nanoparticles. Copyright (C) 2017 VBRI Press.
\end{abstract}

Keywords: Nanoparticles, antimicrobial activity, staphylococcus aureus, pseudomonas aeruginosa.

\section{Introduction}

The re-emergence of infectious diseases (e.g. Ebola haemorrhagic fever, meningitis and tuberculosis) and increasing rates of resistant bacterial strains remains a big threat to health worldwide [1]. Bacteria develop resistance because they adapt to different antibiotics. Some of the pathogenic microorganisms that cause infections and fatal disease are from the Enterococcus, Staphylococcus, Bacillus and Streptococcus genera [2].

Antibiotics have been used as major treatment for such infections. Microorganisms, however have developed resistance towards these antibiotics. Due to emerging resistant bacterial strains, nanoparticles are now being used as antibacterial agents to fill the gaps where antibiotics fail. There are several methods that are used to test antimicrobial activity of nanoparticles including disc diffusion, broth dilution, agar dilution and minimum inhibitory concentration. Disc diffusion involves the use of antimicrobial discs which are placed on agar media. After incubation, the zone of inhibition is measured. Dilution methods are used to measure the antimicrobial concentration that can kill organisms [3].
Metal oxides nanoparticles have two pathways of attacking and destroying bacteria. Firstly, the disruption of the bacterial membrane. Secondly, they produce reactive oxygen species (ROS). The nanoparticles bind electrostatically to the bacterial cell wall and destroy the inner components causing the cell to die. Alternatively, they cause lysis by disturbing the respiratory chain of the bacteria. The main aim is to prevent bacterial growth [1].

Silver oxide $(\mathrm{AgO})$ is an inorganic metal that possesses electrical, thermal conductivity and antimicrobial activity. $\mathrm{Ag}$ nanoparticles are frequently prepared via chemical reduction method. There are several reducing agents used for the synthesis of Ag nanoparticles including sodium borohydride, tri- sodium citrate and hydrogen peroxide. Silver nanoparticles antibacterial activity is dependent on their size, the smaller the nuclei the higher the antibacterial activity. Silver is commonly used in the medicinal sector to treat infections, burns and wounds. In the food industries it is used to control food spoilage. Environmentally it acts as a water purifying agent. Maiti et al. [4] reported that bacteria are less prone to develop resistance against $\mathrm{Ag}$ nanoparticles than against conventional antibiotics. Ag nanoparticles as antimicrobial agents are active against pathogens such as 
Escherichia coli, Staphylococcus aureus and Pseudomonas aeruginosa [5].

Titanium oxide $\left(\mathrm{TiO}_{2}\right)$ is a white powder. In nature it occurs as rutile, brookite and anatase mineral. In the study our focus was to produce anatase $\mathrm{TiO}_{2}$ nanoparticles. Anatase nanoparticles have large surface volume and high photo-catalytic activity as compared to other phases. $\mathrm{TiO}_{2}$ is nontoxic to humans. It has a wide range of applications from purifying agents, antimicrobial agents and as coating agents in food industries. Zinc oxide $(\mathrm{ZnO})$ is a wellstudied metal oxide. It is insoluble in water, and it is used as a coating agent in the food, plastic, glass and paint industries. $\mathrm{ZnO}$ nanoparticles exhibit high activity towards Escherichia coli and Staphylococcus aureus. Their activity can be increased by capping these nanoparticles with other antibacterial agents [6].

This study aims to synthesise and characterise silver (Ag), titanium dioxide $\left(\mathrm{TiO}_{2}\right)$ and zinc oxide $(\mathrm{ZnO})$ nanoparticles and to determine their antimicrobial activity.

\section{Experimental}

\section{Materials/ chemicals details}

All chemicals were purchased from Sigma-Aldrich, South Africa. The biomolecules were purchased from Anatech, South Africa.

\section{Material synthesis / reactions}

\section{Silver nanoparticles}

A $0.1 \mathrm{M}$ silver nitrate $\left(\mathrm{AgNO}_{3}\right)$ solution was prepared by dissolving $0.849 \mathrm{~g}\left(\mathrm{AgNO}_{3}\right)$ in $50 \mathrm{ml}$ distilled water in a $100 \mathrm{ml}$ beaker. Sodium borohydride $0.1 \mathrm{M}\left(\mathrm{NaBH}_{4}\right)$ was prepared by dissolving $0.0567 \mathrm{~g} \mathrm{NaBH}_{4}$ in $50 \mathrm{ml}$ distilled water in a $100 \mathrm{ml}$ beaker. An ice bath was prepared and placed on a magnetic stirrer. $15 \mathrm{ml}$ of $\mathrm{NaBH}_{4}$ was measured and poured in a $100 \mathrm{ml}$ beaker in the ice bath. $15 \mathrm{ml}$ of $\mathrm{AgNO}_{3}$ was added drop-wise in the beaker with constant stirring. Polyvinylpyrrolidone (PVP) of $0.2 \mathrm{~g}$ was added to the solution. Mole ratios of $\mathrm{NaBH}_{4}$ and $\mathrm{AgNO}_{3}$ were varied $(1: 1,1: 2 \& 2: 1)$. The solution was stirred for 45 minutes in the ice bath. The solution was then centrifuged at $2000 \mathrm{rpm}$ for 20 minutes. To remove the excess, the precipitate was washed three times with 40 $\mathrm{ml}$ distilled water. The precipitate was dried at $80^{\circ} \mathrm{C}$ in an oven [7].

\section{Zinc oxide nanoparticles}

Ethanol solution $(0.5 \mathrm{M})$ was prepared by measuring $14.652 \mathrm{ml}$ of pure $(99.9 \%)$ ethanol and diluting with distilled water to make a $500 \mathrm{ml}$ solution. A solution of Zinc nitrate $\left(\mathrm{Zn}\left(\mathrm{NO}_{3}\right)_{2} .4 \mathrm{H}_{2} \mathrm{O}\right)$ was prepared by dissolving $2.62 \mathrm{~g}\left(\mathrm{Zn}\left(\mathrm{NO}_{3}\right)_{2} \cdot 4 \mathrm{H}_{2} \mathrm{O}\right)$ salt in $10 \mathrm{ml}$ of $0.5 \mathrm{M}$ ethanol with constant stirring using a magnetic stirrer for 1 hour. A solution of sodium hydroxide $(\mathrm{NaOH})$ was prepared by dissolving $0.0399 \mathrm{~g}(\mathrm{NaOH})$ in $10 \mathrm{ml}$ of $0.5 \mathrm{M}$ ethanol with constant stirring using a magnetic stirrer for 1 hour. After, $\mathrm{NaOH}$ solution was added drop-wise into a solution of $\mathrm{Zn}\left(\mathrm{NO}_{3}\right)_{2}$ with constant stirring at a higher speed for $45 \mathrm{~min}$. Polyvinylpyrrolidone of $0.2 \mathrm{~g}$ was added to the solution. The reaction was allowed to proceed for 2 hours after complete addition of $\mathrm{NaOH}$. After 2 hours, the beaker was sealed and allowed to settle overnight. The mole ratio of $\mathrm{Zn}\left(\mathrm{NO}_{3}\right)_{2}$ was varied (1:1, 1:2 \& 1:3). The solution was centrifuged at $2000 \mathrm{rpm}$ for 20 minutes. The precipitate was washed three times with $40 \mathrm{ml}$ deionized water to remove the excess. The precipitate was dried in a muffle furnace at $500^{\circ} \mathrm{C}$ for 2 hours [8].

\section{Titanium dioxide nanoparticles}

A $25 \mathrm{ml}$ solution of acetic acid $(\mathrm{AcOH})$ was prepared by measuring $0.43 \mathrm{ml}$ of concentrated acetic acid and diluted with distilled water in a $50 \mathrm{ml}$ beaker. Acetic acid solution was placed on a magnetic stirrer. $2.58 \mathrm{ml}$ of titanium tetrabut-oxide (TBT) was added drop-wise into $25 \mathrm{ml}$ acetic acid with constant stirring for 45 minutes. Polyvinylpyrrolidone of $0.2 \mathrm{~g}$ was added to the solution. After 45 minutes, the mixed solution of TBT and $\mathrm{AcOH}$ was allowed to stand overnight at room temperature. The mole ratio of $\mathrm{AcOH}$ and $\mathrm{TBT}$ were varied $(1: 1,1: 2 \&$ 1:3). The solution was centrifuged at $2000 \mathrm{rpm}$ for 20 minutes. The precipitate was washed with $40 \mathrm{ml}$ deionized water and finally dried in an oven at $80^{\circ} \mathrm{C}$. To obtain pure anatase $\mathrm{TiO}_{2}$ phase, the prepared powder was calcined in a muffle furnace at $400^{\circ} \mathrm{C}$ for 2 hours [9].

\section{Maintenance and growth of bacterial strains}

All the bacterial strains were collected from the Vaal University of Technology Biotechnology laboratory. The strains were grown and maintained on nutrient agar at $37^{\circ} \mathrm{C}$ for 24 hours and subcultured weekly. Stock cultures were stored at $4^{0} \mathrm{C}$. Below (Table 1) is a list of the bacteria that were used for the antimicrobial studies.

Table 1. Organisms that were used for antimicrobial studies.

\begin{tabular}{ll}
\hline Microorganisms & Gram stain \\
\hline Escherichia coli $\mathrm{DH} 5^{\mathrm{a}}$ & Negative \\
Klebsiella pneumoniae & Negative \\
Pseudomonas aeruginosa & Negative \\
Bacillus cereus & Positive \\
Bacillus subtilis & Positive \\
Staphylococcus aureus & Positive \\
\hline
\end{tabular}

\section{Results and discussion}

Fig. 1a, shows UV-Vis spectra of silver nanoparticles for different mole ratios $(1: 1,1: 2$ and $2: 1$ mole ratios of silver nitrate to sodium borohydride). A maximum Plasmon absorption band at $400 \mathrm{~nm}$ was observed for all the mole ratios. This confirmed the formation of silver nanoparticles using the chemical reduction method [7]. A surface Plasmon resonance (absorption band) is due to the vibration of electrons of metal nanoparticles when they come in contact with light (UV light) [10]. Based on the mole ratios, different absorbances were observed. A low absorbance was observed for $1: 1$ and $2: 1$ (mole ratios). This can be due to the imbalance of chemicals. On the 
other hand 1:2 (mole ratio) of the prepared nanoparticles showed a high absorbance. The sample has more molecules that interacted with the light intensity of UV. This increased the absorbance of the light absorbed, hence high concentration results in more bonds and electrons to absorb the light [11].

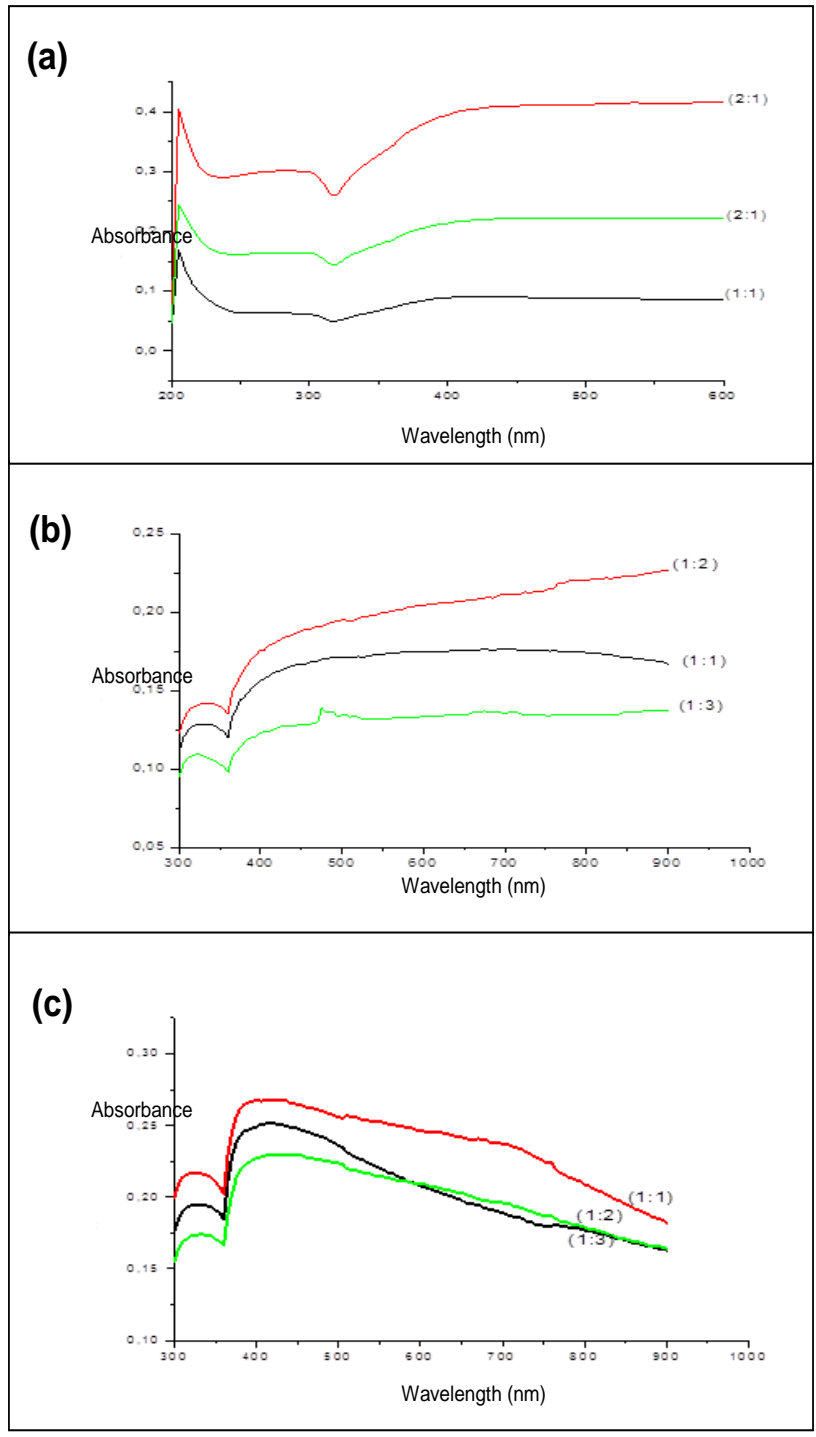

Fig. 1. UV-Vis spectra for (a) silver, (b) titanium dioxide and (c) zinc oxide nanoparticles with different mole ratios.

Fig. 1b shows the UV-Vis spectra for titanium dioxide nanoparticles with different mole ratios. All the three samples show an absorption band that starts at $360 \mathrm{~nm}$. This proves the formation of titanium dioxide nanoparticles during the synthesis. According to Benito et al. titanium dioxide nanoparticles are characterized by an absorption band between 250 and $420 \mathrm{~nm}$ [12; 13]. Fig. 1c shows UV-Vis spectra of zinc oxide nanoparticles with different mole ratios. According to Oladran \& Olabisi zinc oxide nanoparticles are characterized by an absorption band between 270 and $400 \mathrm{~nm}$ [8].

Fig. 2a, shows the FTIR of nanoparticles of 1:2 mole ratio. FT-IR spectra located at $705.88 \mathrm{~cm}^{-1}$ represent the formation of $\mathrm{Ag}$ nanoparticles. The band at $2101.62 \mathrm{~cm}^{-1}$ represents the $\mathrm{O}-\mathrm{H}$ bonds. A stretching band located at $1758.74 \mathrm{~cm}^{-1}$ represents the vibration of $\mathrm{NO}_{2}$ group. Figure $2 \mathrm{a}$, shows nanoparticles of mole ratio 2:1. A peak at $984.34 \mathrm{~cm}^{-1}$ represents the formation of $\mathrm{Ag}$ nanoparticles. Bands observed between 2500 and 3700 $\mathrm{cm}^{-1}$ shows the vibration of $\mathrm{O}-\mathrm{H}$ group. A band at $1386.75 \mathrm{~cm}^{-1}$ represents the formation of $\mathrm{NO}_{2}$ bond [14].

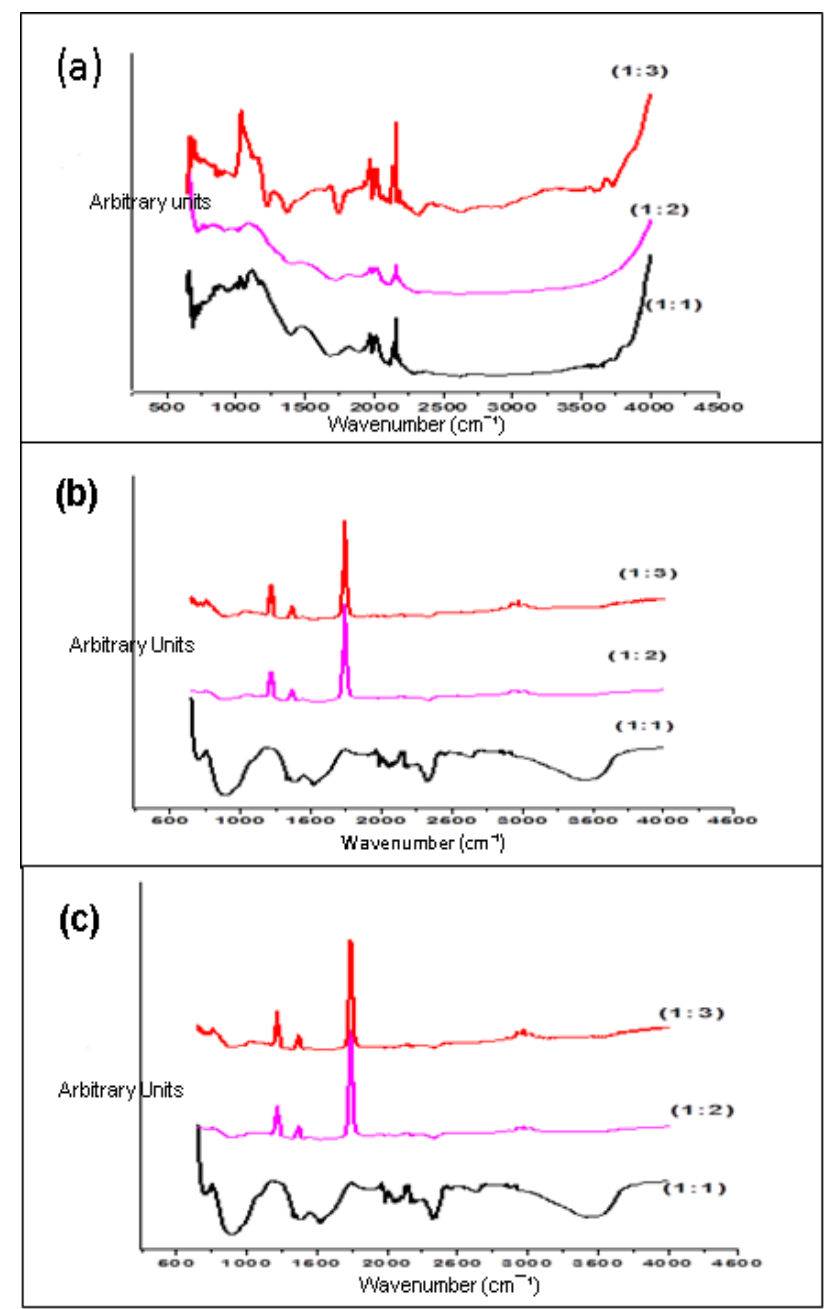

Fig. 2. FTIR spectra for (a) silver, (b) titanium dioxide and (c) zinc oxide nanoparticles with different mole ratios.

Fig. 2b, shows the FT-IR spectra of titanium dioxide nanoparticles with different mole ratios. Sample (a) and (b) show a similar pattern. According to Bagheri et al. [15] peaks between 900 and $850 \mathrm{~cm}^{-1}$ resemble the formation of O-Ti-O bonds. Peaks between 1100 and $1700 \mathrm{~cm}^{-1}$ are characteristics of hydroxyl group and the absorbance of water [16]. Sample (c) shows a different pattern with two bands at 775.21 and $950.63 \mathrm{~cm}^{-1}$. The latter band corresponds to the formation of O-Ti-O bonds. There were no peaks observed at $2900 \mathrm{~cm}^{-1}$ for all the prepared nanoparticles, which means that all organic compounds were removed during calcination [16].

Fig. 2c, shows FT-IR spectra of synthesised zinc oxide with different mole ratios. Sample (a) shows peaks at $687.72 \mathrm{~cm}^{-1}$ which is attributed to the formation of $\mathrm{Zn}-\mathrm{O}$ bond $[17 ; 18]$. The stretching band at $1423.54 \mathrm{~cm}^{-1}$ 
corresponds to carbonyl group $(\mathrm{C}=\mathrm{O})$ and $2116.69 \mathrm{~cm}^{-1}$ show hydroxyl group $(\mathrm{O}-\mathrm{H})$ vibrations that diminishes from the sample that is annealed at high temperature [17]. Peaks at 3490, 2344 and $1983 \mathrm{~cm}^{-1}$ correspond to O-H group present in the sample [19]. Sample (b) shows a peak at $915 \mathrm{~cm}^{-1}$ which correspond to the formation of $\mathrm{Zn}-\mathrm{O}$ bonds. Stretching bands between at 1750 and $2500 \mathrm{~cm}^{-1}$ attribute to the vibration of $\mathrm{C}=\mathrm{O}$ and $\mathrm{O}-\mathrm{H}$ groups. It also shows that the sample was annealed at high temperature [17]. Sample (c) shows a peak at $738 \mathrm{~cm}^{-1}$ which corresponds to $\mathrm{Zn}-\mathrm{O}$ bond. The peak at 1386.75 $\mathrm{cm}^{-1}$ corresponds to $\mathrm{C}=\mathrm{O}$ vibration. Peaks between 1700 and $2500 \mathrm{~cm}^{-1}$ they correspond to the vibration of $\mathrm{O}-\mathrm{H}$ bonds. Fig. 3a shows the TGA results for silver nanoparticles. Two weight loss stages were observed (figure 3a) between $100{ }^{\circ} \mathrm{C}$ and $400^{\circ} \mathrm{C}$ for $(1: 2$ and 2:1). In the first stage weight was lost from $100^{\circ} \mathrm{C}$ to $300^{\circ} \mathrm{C}$. This was due to the evaporation of moisture $[13 ; 20]$. The second drop was from $300{ }^{\circ} \mathrm{C}$ to $400{ }^{\circ} \mathrm{C}$. This was due to the degrading of some un-reacted materials [20]. There was no weight loss observed from $400{ }^{\circ} \mathrm{C}$ to $700{ }^{\circ} \mathrm{C}$. This shows the stability of the pure synthesized silver nanoparticles [21]. Still in figure 3a, the 1:1 (mole ratio) nanoparticles exhibit a drastic weight loss from room temperature to $700^{\circ} \mathrm{C}$. This is an indication of unstable nanoparticles. Hence, they cannot be used for application studies. This can be due to the imbalance of chemicals.

Fig. 3b shows TGA curves of titanium dioxide nanoparticles of different mole ratios. In figure $3 \mathrm{~b}$, samples at all mole ratios show single continuous weight loss from room temperature to $700^{\circ} \mathrm{C}$, at percentage losses of $2.28 \%(1: 1), 5.378 \%(1: 2)$ and $5.07 \%(1: 3)$. The weight loss in the $100^{\circ} \mathrm{C}$ region was attributed to the release of water and the subsequent loss was due to the breakdown of the PVP in the sample [22]. At (1:2) mole ratio, a single weight loss stage which range from room temperature to $300^{\circ} \mathrm{C}$ was recorded. From $300^{\circ} \mathrm{C}$ the sample did not show any weight loss till $700^{\circ} \mathrm{C}$ (It remained constant). This shows the stability of the nanoparticles according to Bagheri et al. [15]. The sample of 1:3 mole ratio, shows two weight loss stages. The first stage ranges from room temperature to $300^{\circ} \mathrm{C}$; this is due to a combined process of removal of water $\left(100^{\circ} \mathrm{C}\right)$ and un-reacted materials $\left(300^{\circ} \mathrm{C}\right)$. The second stage ranges from $300^{\circ} \mathrm{C}$ to $700^{\circ} \mathrm{C}$. This is due to the decomposition of PVP from the sample [22].

Fig. 3c shows TGA curves for zinc oxide synthesized nanoparticles with different ratios. In Fig. 3, the 1:1 mole ratio sample shows that a small amount of weight loss has accrued (about $1 \%$ ) partly caused by evaporation of water from the sample at $100^{\circ} \mathrm{C}$. The $1: 2$ mole ration sample shows three weight loss stages. The first stage from 100 to $200{ }^{0} \mathrm{C}$ is related to the removal of moisture from the sample. Second stage from 540 to $670{ }^{\circ} \mathrm{C}$ is due to decomposition of PVP [19]. The 1:3 mole ratio sample shows two weight loss stages. The first stage is between 100 to $360{ }^{\circ} \mathrm{C}$ and is attributed to the evaporation of moisture and decomposition of un- reacted material. The second stage ranges from 400 to $650{ }^{\circ} \mathrm{C}$ due to the decomposition of PVP from the sample.

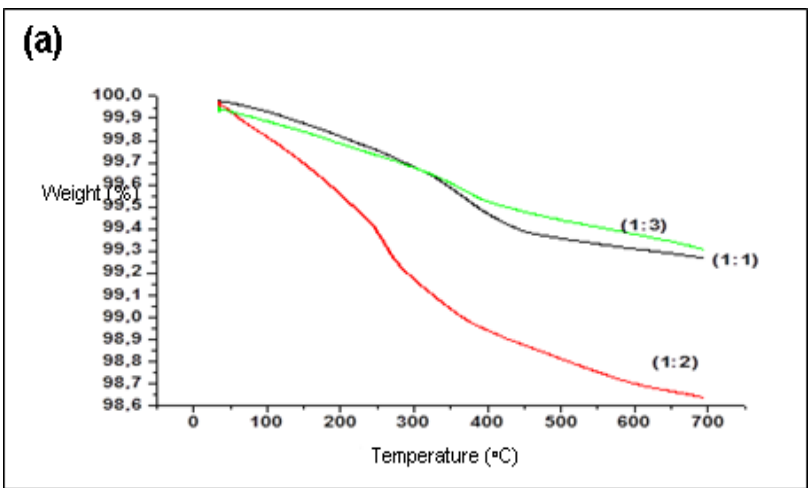

(b)

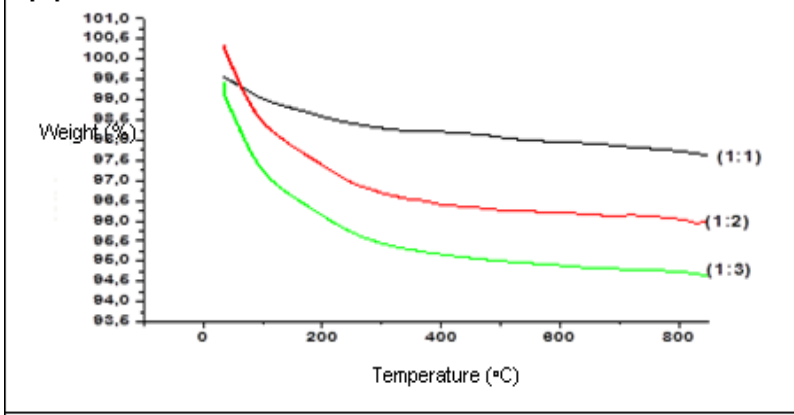

(c)

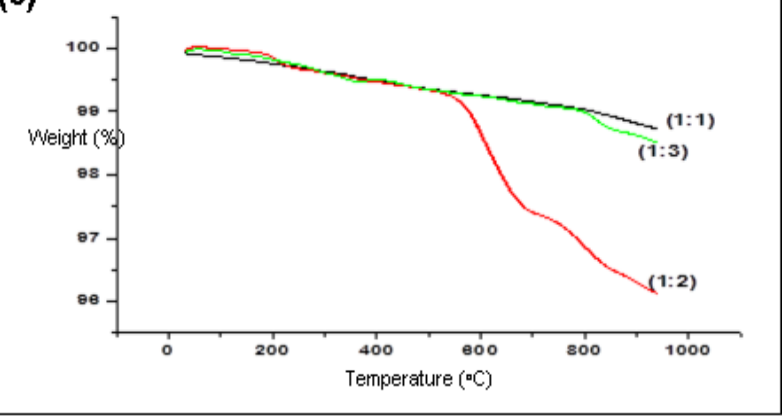

Fig. 3. TGA spectra for (a) silver, (b) titanium dioxide and (c) zinc oxide nanoparticles with different mole ratios

The TEM micrographs and histograms of $\mathrm{Ag}, \mathrm{TiO}_{2}$ and $\mathrm{ZnO}$ nanoparticles are shown in figure 4. TEM micrograph (fig. 4a) shows mixed shapes $\mathrm{Ag}$ nanoparticles of mole ratio 1:2. The particle size distribution of the single nanoparticle ranges from 0.5 to $3 \mathrm{~nm}$ in diameter. This confirms that the particles are in the nanometer range. The image shows aggregated nanoparticles, this means that PVP was limiting. PVP is used to stabilize and prevent agglomeration of the nanoparticles [23].

Fig. 4b shows the micrograph of $\mathrm{TiO}_{2}$ of mole ratio 1:2. The image shows mixed in shape nanoparticles with particle size between 2 to $12 \mathrm{~nm}$ in diameter. It is clear from the image that particles are not agglomerated as compared to $\mathrm{Ag}$ nanoparticles micrograph. The morphology and $\mathrm{ZnO}$ nanoparticles and size distribution is shown on figure $4 \mathrm{c}$. The histogram shows that the particle size ranges from 2 to $12 \mathrm{~nm}$ in diameter. The micrograph shows mixed in shape $\mathrm{ZnO}$ nanoparticles. There is much less agglomeration as compared to $\mathrm{Ag}$ nanoparticles. 


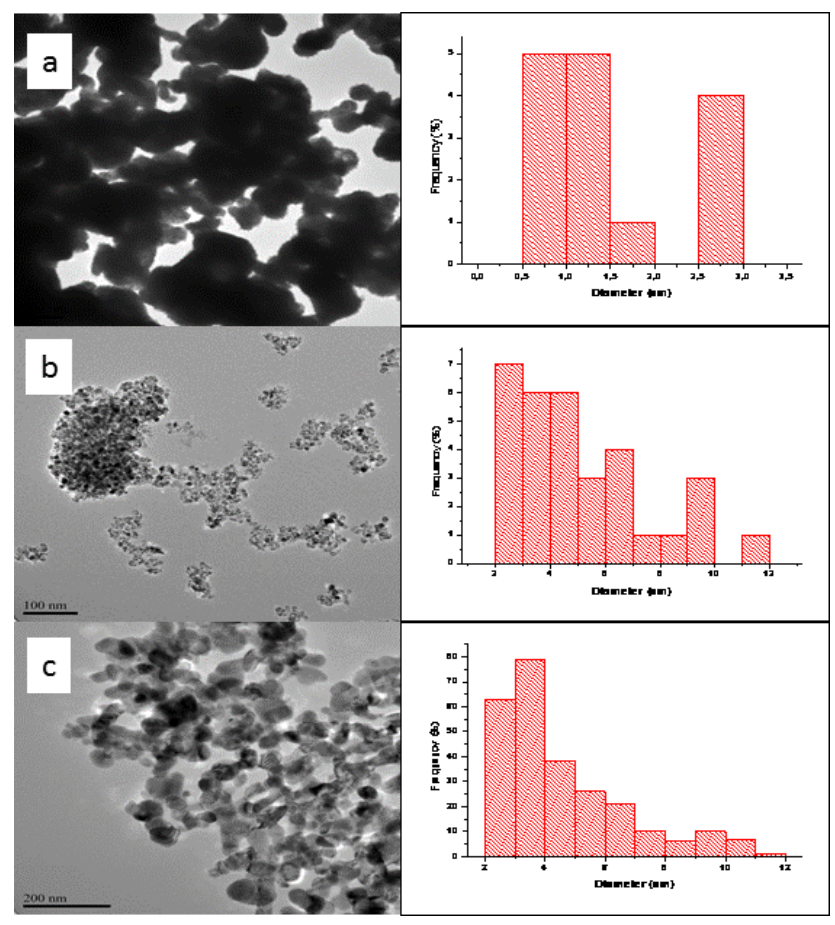

Fig. 4. TEM micrographs of (a) $\mathrm{Ag}$, (b) $\mathrm{TiO}_{2}$ and (c) $\mathrm{ZnO}$ nanoparticles and histogram of particle size distribution

Table 2 shows disc diffusion results after adjusting the concentration of the nanoparticles to $200 \mathrm{mg} / \mathrm{ml}$. Six organisms were used throughout the test. The $\mathrm{Ag}, \mathrm{TiO}_{2}$ and $\mathrm{ZnO}$ nanoparticles at concentration $25,50 \& 100$ $\mathrm{mg} / \mathrm{ml}$ showed no bacterial inhibition as compared to 200 $\mathrm{mg} / \mathrm{ml}$. At a concentration of $200 \mathrm{mg} / \mathrm{ml} \mathrm{Ag}$ nanoparticles showed antibacterial activity against selected bacteria including Escherichia coli $(7 \mathrm{~mm})$, Bacillus cereus $(9$ $\mathrm{mm})$, Bacillus subtilis $(6 \mathrm{~mm})$ and Klebsiella pneumoniae was the most sensitive bacteria with $11 \mathrm{~mm}$ zone of inhibition (Table 2).

Masoud et al. and Okafor et al. conducted studies and reported that Klebsiella pneumoniae was the most sensitive organism towards silver [24; 25]. Maita et al. [4] showed that inhibition depends upon silver nanoparticle concentration, so when silver concentration is increased the bacterial concentration was found to decrease. Ghosh \& Ramamoorthy [26] also reported that antibacterial activity of silver is dependent on size and concentration. The antibacterial activity is due to their size and large surface area volume. Ag particles managed to penetrate through the membrane of selected gram negative and positive bacteria. It appears that $\mathrm{Ag}$ nanoparticles are bactericidal at high concentration. Pseudomonas aeruginosa and Staphylococcus aureus were resistant towards all the nanoparticles at any given concentration. $\mathrm{TiO}_{2}$ and $\mathrm{ZnO}$ nanoparticles didn't show antibacterial effects against the tested bacteria. It is not surprising to see $\mathrm{TiO}_{2}$ and $\mathrm{ZnO}$ nanoparticles showing no antibacterial activity. Parthasarathi \& Thilagavathi [28], Shi et al. [9] and Tariq et al. [27] reported that the activity of both nanoparticles is limited and dependent on size, morphology of nanoparticles and the characteristics of the organism being tested. Small nanoparticles are more effective than large nanoparticles. Padmavathy \& Vijayaraghavan (2008) showed that $\mathrm{ZnO}$ nanoparticles of $12 \mathrm{~nm}$ are more effective than suspension with larger particle size [29]. These nanoparticles are active against gram negative bacteria rather than to gram positive. Gram positive bacteria have a thicker $50 \%$ peptidoglycan layer than gram negative [30]. This thick layer makes it difficult for the nanoparticle to penetrate or disrupt the cell membrane. Zones of inhibition were observed where streptomycin (positive control) was used with a large zone of inhibition of $23 \mathrm{~mm}$ for Bacillus cereus. The tested bacteria were inhibited by this antibiotic. No inhibition was observed on the negative controls.

Table 2: Growth inhibitory effects of silver, titanium dioxide and zinc oxide nanoparticles (200 mg/ml) against bacteria (values in $\mathrm{mm}$ ).

\begin{tabular}{llllll}
\hline \multicolumn{1}{c}{ Bacteria } & \multicolumn{3}{c}{ Nanoparticles } & \multicolumn{2}{c}{ Controls } \\
& Ag & TiO $_{2}$ & ZnO & Negative & Positive \\
\hline E. coli DH5 ${ }^{a}$ & $7 \mathrm{~mm}$ & $0 \mathrm{~mm}$ & $0 \mathrm{~mm}$ & $0 \mathrm{~mm}$ & $19 \mathrm{~mm}$ \\
K. pneumoniae & $11 \mathrm{~mm}$ & $0 \mathrm{~mm}$ & $0 \mathrm{~mm}$ & $0 \mathrm{~mm}$ & $20 \mathrm{~mm}$ \\
S. aureus & $0 \mathrm{~mm}$ & $0 \mathrm{~mm}$ & $0 \mathrm{~mm}$ & $0 \mathrm{~mm}$ & $15 \mathrm{~mm}$ \\
B. cereus & $9 \mathrm{~mm}$ & $0 \mathrm{~mm}$ & $0 \mathrm{~mm}$ & $0 \mathrm{~mm}$ & $23 \mathrm{~mm}$ \\
P. aeruginosa & $0 \mathrm{~mm}$ & $0 \mathrm{~mm}$ & $0 \mathrm{~mm}$ & $0 \mathrm{~mm}$ & $14 \mathrm{~mm}$ \\
B. subtilis & $6 \mathrm{~mm}$ & $0 \mathrm{~mm}$ & $0 \mathrm{~mm}$ & $0 \mathrm{~mm}$ & $17 \mathrm{~mm}$ \\
\hline
\end{tabular}

Resazurin dye was used as a growth indicator. Active bacterial cells reduce the Resazurin dye to produce pink colour. Blue colour indicates inhibition of the bacteria. Tests were done in triplicate. Ag nanoparticles showed inhibition for several bacteria such as Bacillus cereus, Klebsiella pneumoniae, Escherichia coli and Bacillus subtilis for the initial concentration $33.34 \mathrm{mg} / \mathrm{ml}$ only (Fig. 5). Ag nanoparticles were less effective against Pseudomonas aeruginosa and Staphylococcus aureus. These results are comparable to disc diffusion. Titanium dioxide and $\mathrm{ZnO}$ nanoparticles were less effective against all the organisms at all concentrations as shown by the appearance of pink colour. These extracts were unable to kill the organisms. It is reported in the literature that the activity of both nanoparticles is limited and dependent on size, morphology of nanoparticles and the characteristics of the organism being tested [30].

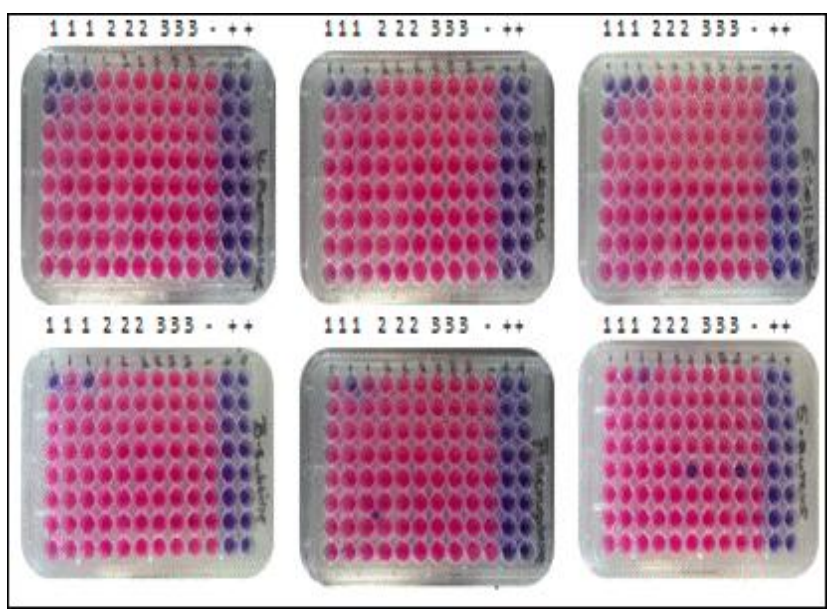

Fig. 5. MIC results (1) represents silver nanoparticles, (2) titanium dioxide, (3) zinc oxide, (-) negative control and (+) positive controls. 
Small nanoparticles are more effective than large nanoparticles. They also active against gram negative bacteria because they have less peptidoglycan layer than gram positive [30]. This thick layer makes it difficult for the nanoparticle to penetrate or disrupt the cell membrane. No colour changes were observed where streptomycin (antibiotic) was used. Negative control showed growth of the tested bacteria. The antibiotic (positive control) managed to inhibit the bacterial growth even at low concentration of $0.026 \mathrm{mg} / \mathrm{ml}$. These controls were used to make sure that the solvent doesn't have any inhibitory effects and to make sure the test is working.

\section{Conclusion}

This study showed that chemical reduction and precipitation methods can be used for the synthesis of silver, titanium dioxide and zinc oxide nanoparticles due to its purity and cost-effectiveness. The formation of these nanoparticles was confirmed by UV-Vis spectroscopy, FTIR, TGA and TEM. TEM analysis confirmed that the synthesized nanoparticles were in the nanometer range. The chemical reduction and precipitation methods produced mixed shaped nanoparticles between the ranges of 0.5 to $12 \mathrm{~nm}$. Based on the results obtained after characterization, second mole ratios of $\mathrm{Ag}, \mathrm{TiO}_{2}$ and $\mathrm{ZnO}$ nanoparticles were used for application studies. Silver nanoparticles inhibited both gram positive and negative bacteria. Titanium dioxide and zinc oxide nanoparticles didn't show any antibacterial activity. The antibacterial activity of $\mathrm{Ag}$ nanoparticles increases with increasing concentration of nanoparticles.

\section{Acknowledgements}

This work was supported by the Departments of Chemistry/Biotechnology and the Institute of Chemical and Biotechnology, Vaal University of Technology, South Africa.

\section{Author's contributions}

Conceived the plan: MJK, NL, KK, ; Performed the expeirments: MDTM, KK; Data analysis: MJK, FMM, VEP, SJM, MDTM, KK; Wrote the paper: MJK, KK, NL. Authors have no competing financial interests.

\section{Supporting information}

Supporting informations are available from VBRI Press.

\section{References}

1. Beyth, N.; Houri-Haddad, Y.; Domb, A.; Khan, W.; Hazan, R; J. Evid. Based Complementary Altern. Med., 2015, Article ID 246012 ,

16 pages.

DOI: $h$ ttp://dx.doi.org/10.1155/2015/246012

2. Seil, J. T.; \& Webster, T. J; Int. J. Nanomedicine., 2012, 2012, 2767.

DOI https://doi.org/10.2147/IJN.S24805

3. Vineetha, N.; Vignesh, R. A.; Sridhar, D.; 2015. Int. J. Appl. Res, 1,624 .

4. Maiti, B.; Krishnan, D.; Barman, G.; Ghosh, S. K.; Laha, J. K.; J. Anal. Sci. Technol., 2014, 5, 2. DOI: $10.1186 / \mathrm{s} 40543-014-0040-3$
5. Costescu, A.; Ciobanu, C. S.; Iconaru, S. L.; Ghita, R. S.; Chifiriuc, C. M.; Marutescu, L. G.; Predoi, D.; J Nanomater., 2013, 1,5 .

DOI: http://dx.doi.org/10.1155/2013/194854

6. Haghi, M.; Hekmatafshar, M.; Janipour, M. B.; Gholizadeh, S. S.; Faraz, M. K.; Sayyadifar, F.; Ghaed, M.; 2012. Intl. J. Adv. Biotec. Res., 2012, 3, 621.

DOI: http://www.bipublication.com

7. Rashid, M.U.; Bhuiyan, K. H.; Quayum, M. E.; Dhaka University J. Pharm.Sci.,2013,12,29.

DOI: http://dx.doi.org/10.3329/dujps.v12i1.16297

8. Oladran, A. A.; Olabisi, I. A.; Asian J. Natur. Appl. Sci., 2013, 2, 14.

DOI: www.ajsc.leena-luna.co.jp

9. Parthasarathi, V.; Thilagavathi, G.; J. Text. Apparel Technol. Manag., 2009, 6, 2.

10. Panigrahi, T.; Master Dissertation. 2013. National Institute of Technology. India.

11. Kerner, N.; Hartman, K.; 2012. Generating and using a Calibration Graph. http://open.umich.edu/site/default/files/2012-experimentii-beers-law-nkerner-khartma-handout.pdf [ Accessed : 02/ 10/ 2016]

12. Benito, H. E.; Sanchez, T. D. A.; Alamilla, R. G.; Enriquez, J. M. H.; Robles, G. S.; Delgado, F. P; Braz. J. Chem. Eng., 2014, 31, 737.

DOI: http://dx.doi.org/10.1590/0104-6632.20140313s00002506

13. Khan, M. A.; Kumar, S.; Ahamed, M.; Airokayan, S. A; Alsalhi, M. S.; Nanoscale Res. Lett., 2011, 6, 434.

DOI: $10.1186 / 1556-276 \mathrm{X}-6-434$

14. Sodha, K. H.; Jadav, J. K.; Gajera, H. P.; Rothod, K. J.; Int. J. Pharm. Bio. Sci., 2015, 6, 199.

15. Bagheri, S.; Shameli, K.; HAMID, S. B.A.; J. Chem., 2013, 13, 2. DOI: $10.1155 / 2013 / 848205$

16. Devi, R. S.; Venckatesh, R.; Sivaraj, R.; Int. J. Innovative Res. Sci. Eng. Technol., 2014, 3, 15207.

DOI: $10.15680 /$ IJIRSET.2014.0308020

17. Ghosh, S. P.; Masters Dissertation. National Institute of Technology, 2012.

Website: http://ethesis.nitrkl.ac.in/3259/1/projectfinaal.pdf

18. Akhtar, T.; Alam, M.; Inter. J. Sci. Res., 2012, 1, 1362.

19. Nejati, K.; Rezvani, Z.; Pakizevand, R.; Inter. Nano Lett. 2011, 1 , 75.

20. Alghoraibi, I.; Alahmad, A.; Int. J. Chem. Tech. Res., 2014, 6, 872.

21. Saware, K.; Salimath, B.; Sawle, B.; Jayanthi, K.; Abbaraju, V.; Inter. J. Res. Eng. Technol., 2014, 3, 867.

DOI: http://www.ijret.org

22. Ba-abbad, M. M.; Kadhum, A. A. H.; Mohamad, A. B.; Takriff, M. S.; Kamaruzzaman, S.; Int. J. Electrochem. Sci., 2012, 7, 4874.

23. Malina, D.; Sabezak-Kupiec, A.; Wzorek, Z.; Kowalski, Z.; 2012. Dig. J. Nanomater. Bios., 2012, 7, 1529.

24. Masoud, E. A.; Aal-Hajry, A. M.; All-Marrani, A.; Int. J. Curr. Microbiol. App. Sci., 2016, 5, 226. DOI: $10.20546 /$ ijcmas.2016.504.028

25. Okafor, F.; Janen, A.; Kuthtareva, T.; Edwards, V.; Curley, M.; Int. J. Environ. Res. Public Health. 2013, 10, 5221. DOI:10.3390/ijerph10105221

26. Ghosh, B.; Ramamoorthy, D.; Int. J. Chem. Sci., 2010, 8, 31.

27. Shi, L.; Li, H.; Zheng, W.; Zhao, Y.; Jin, Y.; Tang, Z. Food Addit. Contam. Part A Chem Anal. Control Expo. Risk Assess. A review., 2014, $1,12$. DOI: $10.1080 / 19440049.2013 .865147$

28. Tariq, J.; Javed, I.; Muhammad, I.; Zakaullah, M.; Saijad, H. N.; Noor, B.; Int J Nanomedicine., 2013, 8, 3679. DOI: $10.2147 / \mathrm{IJN}$.S45439

29. Padmavathy, N.; Vijiyaraghavan, R.; Sci. Technol. Adv. Mater., 2008, 9,5004 DOI: $10.1088 / 1468-6996 / 9 / 3 / 035004$

30. Willey, J. M.; Sherwood, L. M.; Woolverton, C. J (Eds); Prescotts Microbiology, McGraw-Hill Education, USA, 2011. ISBN: 10.0073402400 